\title{
Bio Event
}

National Cancer Institute

\section{Source}

National Cancer Institute. Bio Event. NCI Thesaurus. Code C44172.

An abstract class to capture the concept of an event (either in the laboratory or a computational analysis). (caMAGE) 